Island Studies Journal, Vol. 7, No. 1, 2012, pp. 99-118

The Globalization of the Arctic: Negotiating Sovereignty and Building Communities in Svalbard, Norway

Adam Grydehøj

Island Dynamics, Whitstable, UK

agrydehoj@islanddynamics.org

Anne Grydehøj

School of European Culture and Languages

University of Kent, Canterbury, UK

a.grydehoej@kent.ac.uk

and

Maria Ackrén

Ilisimatusarfik/University of Greenland

Nuuk, Greenland

maac@samf.uni.gl

ABSTRACT: The Arctic archipelago of Svalbard has been under Norwegian sovereignty since 1920 yet remains subject to international law. Until recently, the islands' only major economic activities were unprofitable Russian and Norwegian funded mining operations aimed at maintaining continuous settlement. Now, however, Norway's top-down governance of the territory has been complicated by the emergence of economic diversity, multinationalism, and local democracy in the town of Longyearbyen. Simultaneously, China and other states are promoting their Arctic interests by exploiting the preoccupation with Russia that characterizes Norway's Svalbard policy. By interpreting Svalbard's local communities through the prism of international relations, this article highlights the practical challenges to creating genuinely international territories.

Keywords: Arctic; China; governance; international relations; islands; Norway; Russia; sovereignty; Spitsbergen; Svalbard

(C) 2012 Institute of Island Studies, University of Prince Edward Island, Canada

\title{
Introduction
}

Although the Cold War has ended, international relations remain complex in the High North. The present paper considers Svalbard, a territory that has been the subject of jurisdictional wrangling since its discovery in the $16^{\text {th }}$ Century.

The Svalbard archipelago, with a total landmass of $61,020 \mathrm{~km}^{2}$, is composed of numerous islands between mainland Norway and the North Pole. Only Spitsbergen, the largest of these islands, is permanently inhabited. Around $60 \%$ of Svalbard is covered by ice year round, and 
less than $10 \%$ supports vegetation. As of 1 January 2011, Svalbard had a total population of 2,394 (Statistics Norway, 2011b).

Svalbard is under Norwegian sovereignty, yet its governance is rooted in international law. This paper discusses the treaty that defined Svalbard's jurisdiction and considers how Svalbard is governed today. We contend that Norway's sovereignty over Svalbard is not as absolute as the Norwegian government insists and that Norway must therefore continually reassert this sovereignty through economic activities, national legislation, and international cooperation. Meanwhile, Russia is set on reinforcing uncertainty over Svalbard's jurisdiction; and some other states, most notably the Asian economic powerhouses, have begun exploiting Svalbard's legal status in pursuit of wider Arctic strategies.

Since 2006, the Norwegian government has identified the High North as "Norway's most important strategic priority area in the years ahead" (Norwegian Ministry of Foreign Affairs, 2006). The climate change-induced melting of the polar icecaps presents opportunities for Norway to exploit its longstanding position of strength in Arctic transport, engineering, and other fields. However, it also opens the High North to activities by other Arctic and non-Arctic states. Russia too is focusing on the Arctic, and China has begun making use of the Northern Sea Route and Northwest Passage for shipping manufactured and processed goods to Europe and the Eastern seaboard of the United States (Byers, 2011a, 2011b). The events taking place in and concerning Svalbard may have a major impact on international relations and global trade over the coming century.

Nevertheless, despite - or perhaps as a precondition for - its global importance, the case of Svalbard is a peculiarly island case: the archipelago's insularity - its geographic 'otherness' has led to its simultaneously belonging to everyone and to no one. Svalbard is an example of the periphery being valued by national governments precisely because it is 'peripheral'; and being valued by local residents precisely because it is 'home'.

\section{Svalbard in International Law}

\section{Origins of the Spitsbergen Treaty}

A number of Arctic islands held ambiguous jurisdictional statuses at the start of the $20^{\text {th }}$ Century: Svalbard, Greenland, Jan Mayen, Franz Josef Land, and Wrangel Island were generally considered to be terra nullius, or 'no man's land', i.e. a territory that has never been subject to any state. With the exception of Greenland, none of these islands were home to indigenous populations at the time of their discoveries by peoples of European descent.

Svalbard was discovered by the Dutch explorer Willem Barents in 1596. In 1613, the Muscovy Company, an English whaling operation, claimed exclusive rights to the islands, conflicting with claims of sovereignty forwarded by the then-united kingdom of Denmark-Norway. The Dutch countered with the principle of Mare Liberum, i.e. that the seas belong to everyone. In 1870, the Swedish-Norwegian Council of Ministers considered annexing Svalbard and setting up a colony on the islands, yet practical concerns and opposition from Russia prevented this from being carried out (Wråkberg, 2002: 183). 
Shortly after Norway gained independence from Sweden in 1905, it sought clarification on Svalbard's jurisdiction. Because it had been terra nullius, numerous countries could claim an interest in the archipelago. Norway asserted that the islands were referenced in a $12^{\text {th }}$ Century Icelandic text. The Dutch argued special rights to the islands due to Barents's 1596 discovery and the subsequent semi-permanent Dutch whaling stations. Russia, meanwhile, contested that hunters from its Pomor region had reached Svalbard prior to Barents (Umbreit, 2009: 25). The United Kingdom noted that the Muscovy Company's Robert Fotherby had claimed Spitsbergen for King James I in 1614. At the time, Arctic whaling and seal hunting was still an industry of economic importance to a variety of states. In addition, from 1906, although most of Svalbard's inhabitants were Norwegian, the primary employer on the islands was the Bostonbased Arctic Coal Company (Emmerson, 2010: 90-91).

A joint-sovereignty solution proposed by Norway, Sweden, and Russia in 1910 was strongly opposed by the USA and Germany, and subsequent discussions in 1912 and 1914 likewise proved unsuccessful (Numminen, 2011; Machowski, 1995). The breakthrough came with the 1919 Paris Peace Conference. The Allied Supreme Council granted Norway sovereignty over Svalbard, though with provisions for international activity in the islands, resulting in the 1920 Treaty Concerning the Archipelago of Spitsbergen (hereafter, the Spitsbergen Treaty). That the solution came when it did was the result of a number of factors, including the USA's declining economic interest in Svalbard; the desire of World War I's victors to reward Norway for its aid; and the post-war disempowerment of Germany and unrecognized status of the Bolshevik government in Russia, both countries that had interests in Svalbard and that might otherwise have driven a hard bargain at the negotiating table (Arlov, 2011: 32-34). There were 14 original signatory states, with the Soviet Union and Germany eventually signing the treaty in 1924 and 1925 respectively. ${ }^{1}$ In the event, some of the strongest protests against the Spitsbergen Treaty came from the Norwegian press and parliament, parts of which felt that the treaty and the subsequent Mining Code placed too many restrictions on Norway's sovereignty (Arlov, 2011: 34-38). The treaty was finally ratified in 1925.

In the years following the treaty's signing, jurisdiction over the other disputed Arctic islands was formalized, with sovereignty of Wrangel Island (1924) and Franz Josef Land (1929) going to the Soviet Union, Jan Mayen to Norway (1929), and the Svedrup Islands to Canada (1930). Despite the fact that Denmark's acceptance of the Spitsbergen Treaty was linked to Norway pledging in 1919 to drop its claims to East Greenland (Arlov, 2011: 37), it was only with the 1933 decision by the Permanent Court of International Justice at the Hague that Denmark at last gained internationally recognized sovereignty over all of Greenland (Webb, 1992; Fife, 2008).

\footnotetext{
${ }^{1}$ Treaty signatories now include Afghanistan, Albania, Argentina, Australia, Austria, Belgium, Bulgaria, Canada, Chile, China, Czech Republic, Denmark, Dominican Republic, Egypt, Estonia, Finland, France, Germany, Greece, Hungary, Iceland, India, Italy, Japan, Monaco, Netherlands, New Zealand, Norway, Poland, Portugal, Romania, Russia, Saudi Arabia, South Africa, South Korea, Spain, Sweden, Switzerland, Ukraine, the United Kingdom, the USA, and Venezuela.
} 


\section{Contents of the Spitsbergen Treaty}

The Spitsbergen Treaty provides a framework for Svalbard's governance. For our purposes, its most significant provisions are:

- Article 1: Norway possesses "full and absolute sovereignty" over "all the islands between $10^{\circ}$ and $35^{\circ}$ longitude East of Greenwich and between $74^{\circ}$ and $81^{\circ}$ latitude North".

- Articles 2-3: Nationals of all signatory states may undertake commercial activities "on a footing of absolute equality", subject to Norwegian legislation.

- Article 6: For a limited time, claims were considered on land occupied prior to the treaty's signing. Where valid, title to such land was granted to the claimant.

- Article 7: Nationals of all signatory states may acquire, enjoy, and exercise the right of ownership of property (including mineral rights) on terms of "complete equality".

- Article 8: "Taxes, dues, and fees levied shall be devoted exclusively" to the administration of Svalbard.

- Article 9: Svalbard "may never be used for warlike purposes".

\section{Governing Svalbard}

Norway's primary formal means of exercising sovereignty over Svalbard has been through the office of the Governor (Sysselmannen), who reports to the Ministry of Justice in Norway. In the 1970s, Longyearbyen, Svalbard's largest settlement, began a gradual process of liberalization, necessitating the Governor taking over tasks from the Norwegian mining company and establishing "effective enforcement of Norwegian sovereignty, especially towards foreign agents on the archipelago" (Government of Norway, 1999: §5.4.1). A 1979 royal decree states:

[The Governor] shall seek to coordinate state activities on the archipelago. He [sic] must keep himself informed about any activities that may have significance for this work. $\mathrm{He}$ shall work for the good of Svalbard and, in this context, take those initiatives he considers necessary (Qtd. in Government of Norway, 1999: §5.4.1).

The Governor is thus responsible for such functions as policing, environmental protection, notarial duties, travel and tourism coordination, public information, transport, and contact with foreign settlements in Svalbard (Government of Norway, 1999: §5.4).

Due to the stipulations of the Spitsbergen Treaty's Article 8, all personal and corporate taxes levied in Svalbard go into a separate budget for the archipelago's administration. No money is passed on to Norway's central government. Value-added tax is thus non-existent, and income 
tax (at $8 \%$ ) and corporate tax (at 10\%) are substantially lower than in mainland Norway (Umbreit, 2009: 40). This combination of high wages and low taxes is attractive to potential workers. Government functions are funded through tax revenues and annual grants from Norway (Government of Norway, 1999: §5.3). In 2010, Norwegian government subsidies to Norwegian companies in Svalbard amounted to NOK 388 million (around US\$65 million) (Statistics Norway, 2011d).

\section{Economic Activity in a Shared Territory}

Since its discovery by Barents, Svalbard has hosted a number of economic activities. In the $17^{\text {th }}$ Century, it was the site of Dutch, British, and German whaling camps; in the $18^{\text {th }}$ and $19^{\text {th }}$ Centuries, it was home to Russian, then Norwegian, hunters; and from the start of the $20^{\text {th }}$ Century, activity has focused on mining.

Since the $18^{\text {th }}$ Century, Svalbard has also been a site for scientific expeditions, being visited by British, Norwegian, Swedish, Polish, and German groups. After the signing of the Spitsbergen Treaty, scientific research in Svalbard became institutionalized, most notably with the 1928 founding of what later became the Norwegian Polar Institute (Lüdecke, 2011). Today, NyÅlesund (the world's northernmost permanently inhabited settlement, with a population of around 35) operates as a research centre, containing facilities run by various treaty signatory states. The settlement itself is owned and managed by the public corporation Kings Bay AS. Since 1978, Poland has maintained year-round operations at the Polish Polar Station at Hornsundet, which is manned by around eight people and hosts visiting delegations (Moczadlowski, 2001).

Coal mining in Svalbard began in earnest around 1900. The earliest Svalbard mining companies underwent frequent changes in ownership, with the first Norwegian companies passing to buyers from Russia, the Netherlands, the UK, and the USA. In 1911, Sweden established mines at Pyramiden and Sveagruva but found it necessary to sell Sveagruva to Norway and Pyramiden to Russia in the 1920s. In 1916, the Norwegian government founded the Store Norske Spitsbergen Kulkompani (hereafter, Store Norske), which would later take over the mining at Sveagruva. The Soviet Union likewise took over mining activities in Barentsburg from the Dutch in the early 1930s.

With the Spitsbergen Treaty came regulation of the mining industry via the Mining Code of 1925 , amended by royal decree in 1975 . The Mining Code (\$2) entitles treaty signatory states to search for, acquire, and exploit natural deposits of coal, mineral oils, etc. on an equal footing. This is not to say that all signatory states possess equal mining rights in practice. In accordance with Article 6 of the Spitsbergen Treaty, only a limited period existed in which territory could be claimed and property ownership by foreign states could be grandfathered into the Norwegian regime (Lüdecke, 2011). From the start, Norway sought to overcome some of its Spitsbergen Treaty-imposed weaknesses by purchasing mining rights from other states whenever they became available; and, since the 1930s, Russia has done the same. The result being that, for the past 80 years, these have been the only states to exercise mining rights (Arlov, 2011: 40-41; Umbreit, 2009: 36). For most of the $20^{\text {th }}$ Century, mining was Svalbard's only major commercial activity, sustaining the permanent settlements of Longyearbyen, Ny- 
Ålesund, Pyramiden, Sveagruva and Barentsburg. The right to undertake economic activities on an equal footing means that all signatory states may, for example, make use of the seaways around Svalbard, in compliance with Norwegian environmental regulations.

With a population of about 2,070, Longyearbyen is Svalbard's largest settlement. Around 240 workers commute from Longyearbyen to Sveagruva, the most important of Store Norske's mines, $60 \mathrm{~km}$ to the southeast, on a week-on/week-off basis. Barentsburg, the second-largest settlement, is operated by the Russian state-owned Trust Arktikugol mining company. Barentsburg's population is about half Russian and half Ukrainian (Governor of Svalbard, 2008). In contrast to Longyearbyen, which has grown significantly over the past years, Barentsburg's population has dropped steeply, from 939 in 1998 to 425 today (Statistics Norway, 2011b). The last of Svalbard's settlements to close was the Russian community at Pyramiden, which shut down in 1998. Since 2009, however, Trust Arktikugol has been hosting overnight tourists in container housing and renovating the abandoned Pyramiden Hotel (Terrapolaris, 2010).

Although Store Norske has historically depended on Norwegian state subsidies, it has managed to turn a profit during recent years. Since Store Norske's mines at Svea Nord and Adventdalen are running low on high-quality coal, a new mine is being developed at Lunckefjell. As Store Norske itself notes:

This is important not only for Store Norske and all our staff, but also for the Norwegian presence at Svalbard and for the long-term stability of the community in Longyearbyen (Store Norske, 2011).

Trust Arktikugol has similarly been heavily subsidised by the Russian state. The uncertain profitability - and often, certain unprofitability - of mining operations in Svalbard suggest that the Norwegian and Russian operations exist due to a perceived political need to maintain settlements in the archipelago. The idea exists that "as long as Russia runs mining operations in Svalbard, Norway has to do so too" (Jørgensen, 2004, translation our own).

\section{Longyearbyen: A Community in Constant Transition}

Svalbard's jurisdictional status has inspired unique community-level policy solutions. Until recently, all settlements in Svalbard were company towns. The companies that ran them had de facto control over their populations (who lived there, what work they did, what goods they could purchase, etc.). For instance, in Longyearbyen, Norwegian currency only came into use in 1980, when the central bank of Norway requested that Store Norske cease printing the wage vouchers that had been used instead of money (Store Norske, 2010).

Longyearbyen began its slow normalization process in the mid-1970s. At the time, most of Longyearbyen's residents were employed by Store Norske on shifts of a few years' duration. Local government was non-existent, and the Governor had total de jure jurisdiction. In Evjen's (2001: 36, translation our own) words: 
As long as the Norwegian settlement in Svalbard was viewed purely as a means of exercising Norwegian sovereignty and foreign policy, few people thought along the lines of local self-government. [...] People were generally satisfied with making good money and paying low taxes; lack of political influence on development of the community was a small price to pay. There was not much of a community to develop either: It was more or less a workplace.

Store Norske was responsible for the provision of all community services. In 1989, these functions passed to the subsidiary Svalbard Samfunnsdrift $A S$, which became a fully public corporation in 1993 (Government of Norway, 1999: §7.3.1). Store Norske also transferred functions to other new companies: Spitsbergen Travel AS (tourism operations), Svalbard Nceringsutvikling AS (commercial development), and Svalbard Nceringsbygg AS (commercial property). Differentiating these functions from mining operations made truly diversified development possible.

This was part of a new government policy, starting in the late 1980s, to encourage the development of Longyearbyen's tourism industry (Arlov, 2011: 324-325). The settlement had previously lacked accommodation, dining, and shopping facilities (Government of Norway, 1999: §7.4.4). In 2010, Longyearbyen's hotels and guest houses hosted 60,142 guest nights from tourists and conference/course visitors (Statistics Norway, 2011a). 1993 saw the establishment of UNIS, the University Centre in Svalbard, offering Arctic sciences education. Because of these developments, Longyearbyen's economy was no longer entirely dependent on Store Norske, and over just a few years, the town's service sector grew enormously, with the opening of numerous new shops, hotels, restaurants, and bars. Longyearbyen was transformed into Svalbard's first - and so far, only - economically diverse settlement.

Even today though, most of Longyearbyen's residents are transient, and only a very small minority have local ties going back more than a few decades. In 2008, the town's annual population turnover rate was $23 \%$ (Olsen, 2009). The population of Svalbard's two Norwegian settlements, Longyearbyen and Ny-Ålesund, is also very young $(50 \%$ in the 20 44 age bracket, compared with a Norwegian national average of 34.1\%) (Statistics Norway, $2011 \mathrm{~b}$ ). This transience and youth is partly a result of there being only limited social services in Svalbard: Neither economic support nor long-term medical care are available to residents. Longyearbyen residents thus cannot plan on living out their lives in Svalbard. As Holm (2001: 128-129, translation our own) writes:

Do we know who we are? Of course not, except that we are just visiting, that the situation is temporary, that no matter how happily life is described in questionnaires, it is nevertheless a life in transit. A life where the question of when you are going to travel back south is just as everyday as a child's question of what's for dinner. ... Longyearbyen is not a permanent place.

This transience inhibits the building of sustained community structures; yet, there exists a sense of local identity, with residents embracing a vision of Svalbard culture, even though this culture is characterized precisely by impermanence. Despite the comforts supplied by Longyearbyen's modern amenities, even short-term residents can feel as though they are living 
in the tradition of Svalbard's early miners and explorers. Nightlife locales, such as Huset and Kroa, which benefit from tourist revenue, and which are decorated like cultural tourism sites, with old-time mining themes, are nonetheless regarded as part of the local community and centres of local cultural activity (Grydehøj, 2010).

\section{Creation of the Longyearbyen Community Council}

Only in 2002 did Longyearbyen gain a measure of local democracy, with the creation of the Longyearbyen Community Council (Longyearbyen lokalstyre).

During the Cold War, Norway's Svalbard policy focused on national security; local democracy was not prioritized (Government of Norway, 1999: §14.2.1). Nevertheless, the Local Svalbard Council (Det stedlige svalbardråd) - later recast as the Svalbard Council (Svalbardrådet) was created in 1971. The Svalbard Council possessed a purely advisory role to the Governor. In the mid-1970s, a Norwegian government white paper (Report No. 39 to the Storting, 197475) considered and rejected the institution of local democracy. Indeed, a mid-1980s government white paper (Report No. 40 to the Storting, 1985-86) presented "political, practical and economic obstacles to the development of local democracy following the mainland model" (Government of Norway, 1999: §14.2.1).

Norway felt that maintenance of the Governor's authority was vital in relation to the Spitsbergen Treaty (Government of Norway, 2001: §2.1). Furthermore, the demands of the treaty require Norway to constantly prove its sovereignty in practice:

The credible and effective exercise of sovereignty is dependent on a stable Norwegian presence on Svalbard. Viable local communities are probably the most important feature of this Norwegian presence (Government of Norway, 1999: §2.2.4).

However, the speed of change in Longyearbyen leading up to the 1990s suggested that the Governor's absolute authority was untenable in the long term. Despite its previous reservations, Norway began assessing how local democracy might be achieved within the limits of the Spitsbergen Treaty. With reference to the Svalbard Council, a 1990 report by Geir Ulfstein argued that:

Norway, by virtue of its sovereignty, in principle has freedom of action in respect of increased local democracy. However, Norway has both the right and the obligation to exercise sovereignty, so that fully autonomous settlements cannot be established without conflicting with the Treaty. A basic assumption is that Norway must both formally and effectively have control of any exercise of authority which impinges on the treaty rights of other states. The Svalbard Council can have limited decision-making authority in matters relating to the Norwegian population, but only the right to give an opinion in matters which concern other states or which are of special importance. (Government of Norway, 1999: §14.2.3) 
The government's local democracy plan was finally accomplished with a white paper (Report No. 9 to the Storting, 1999-2000: Svalbard). The resultant legislation gave the Longyearbyen Community Council:

... responsibility for the infrastructure in Longyearbyen, social and area planning, economic planning, business work, production of statistics, development and coordination of social services for children, youths and adults, child protection, social work, youth work, child care services, and political secretariat (Ween, 2011, our translation).

The Governor retained responsibility for these issues elsewhere in Svalbard.

Although there had been a general desire for greater democracy among Longyearbyen's population, the creation of the Longyearbyen Community Council did not meet with universal approval locally. Even in 2005, half of the town's inhabitants opposed the system of local democracy, and those who had resided in Svalbard the longest were the least likely to support the system, in part because of the fear of more bureaucracy and higher taxes. When income tax in Svalbard did indeed rise significantly, the resultant protests were sufficiently strong to cause the Norwegian government to backtrack on the issue (Arlov, 2011: 372-375). One paradoxical result of the changes in governance that took place in the first decade of the new millennium was the strengthening among Longyearbyen residents of support for the Governor's office, which came to be seen less as an appendage of the Norwegian state than as a means of promoting residents' interests in relation to the state (Arlov, 2011: 390-393).

It is always instructive to consider examples of relatively wealthy island communities that are, contrary to the norm, unenthusiastic about the prospect of greater local autonomy (Grydehøj \& Hayward, 2011). The next section reviews how recent demographic developments have further restricted the democratic nature of Longyearbyen's already limited local democracy.

\section{Globalization in Miniature}

Although there was interaction between the residents of Svalbard's Russian and Norwegian settlements in the past, this interaction was managed and was viewed with suspicion by the settlements' respective government authorities (Umbreit, 2009: 42; Tobias, 2006). Svalbard has always been a territory without internal borders, yet there existed a de facto distinction between different national zones. Today, however, the fall of the Soviet Union, the liberalization of Longyearbyen, and the growth of tourism have increased opportunities and demand for Russian-Norwegian interaction. Longyearbyen-to-Barentsburg summer tourism boat trips began in 1986, and there are now regular tourist boat and snowmobile trips, blurring Svalbard's de facto national zones.

Longyearbyen's economic liberalization has also limited Norway's control over community development. As late as 2001, the government asserted that the town should ideally have a maximum of 1,300 residents (Government of Norway, 1999: §2.2.4). As of 1 July 2011, Longyearbyen and Ny-Ålesund had 2,104 residents combined. Of these, 1,741 were Norwegian nationals, and 363 were nationals of other states (Statistics Norway, 2011b). 
Non-Norwegian nationals thus constitute $17.3 \%$ of the Norwegian settlements' population. Because of the Spitsbergen Treaty, Norwegian immigration law is not in force in Svalbard, meaning that non-Norwegian nationals residing in Svalbard cannot achieve Norwegian residence or citizenship by staying in the territory. See Table 1 .

Table 1: Population of Svalbard's Norwegian settlements, broken down by place of residence outside of Svalbard, 1 July 2011.

\begin{tabular}{|l|r|r|r|c|}
\hline $\begin{array}{l}\text { Place of Residence } \\
\text { outside Svalbard }\end{array}$ & Male & Female & Total & $\begin{array}{l}\text { Percentage } \\
\text { of Total }\end{array}$ \\
\hline Norway & 1025 & 716 & 1741 & $82.7 \%$ \\
\hline All Non-Norwegians & 177 & 186 & 363 & $17.3 \%$ \\
\hline Thailand & 38 & 65 & 103 & \\
\hline Sweden & 44 & 31 & 75 & \\
\hline Russia & 14 & 22 & 36 & \\
\hline Germany & 15 & 6 & 21 & \\
\hline Croatia & 7 & 7 & 14 & \\
\hline Denmark & 5 & 6 & 11 & \\
\hline Philippines & 2 & 9 & 11 & \\
\hline Others & 52 & 40 & 92 & \\
\hline
\end{tabular}

Source: Statistics Norway (2011b).

Particularly remarkable is the large number of Thai nationals, making up $4.9 \%$ of the Norwegian settlements' total population. Jensen (2009) has noted that, although small numbers of Thai women came to Svalbard as marriage migrants beginning in the 1970s, Thai immigration has surged since the mid-1990s. These later immigrants sought to escape poor economic conditions in Thailand and were 'recruited' by the pioneer migrants of earlier years. Thailand is not a Spitsbergen Treaty signatory, yet Svalbard's exemption from Norwegian immigration law makes it the only place in Europe for which Thai immigrants do not require a visa. As a result, in contrast to Thai immigration elsewhere in Europe, Svalbard's Thai immigrants are today primarily labour migrants rather than marriage migrants, composed of a mixture of married and unmarried men and women as well as all-Thai family groups.

Also strikingly, besides nationals of Norway, Thailand, and Sweden, Longyearbyen possesses no sizeable population of nationals from any particular country. Rather than being home to a small number of distinct ethnic communities, Longyearbyen's non-Norwegian population is characterized chiefly by diversity: $10.5 \%$ of the Norwegian settlements' total population does not belong to one of the top-three groups of nationals present, and Longyearbyen is home to nationals of around 40 countries (Governor of Svalbard, 2008).

Longyearbyen's multinationalism and the implementation of local democracy have challenged Norway's efforts to manage Svalbard's development and abide by the Spitsbergen Treaty. The Longyearbyen Community Council, as part of the Norwegian state, is not electable by all Longyearbyen residents; rather, it is electable by those Longyearbyen residents who possess voting rights in mainland Norway. Longyearbyen may be an exemplar multinational 
community, but it is not a multinational democracy. For instance, considering Longyearbyen's high level of population mobility, its Thai population is on course to represent one of Svalbard's most stable communities. Considerable numbers of long-term Thai residents are present in a town dominated by short-term residents. Yet Longyearbyen's Thai nationals - like nationals of Russia, Germany, and all other non-Nordic countries - have no right to vote or exercise direct influence on the Longyearbyen Community Council or, indeed, on any other form of government in Svalbard.

\section{Russian-Norwegian Conflict}

As shown above, the framework for community life in Svalbard is driven by Norway's and Russia's desire to affirm their rights in the archipelago. International relations have always been at the core of Svalbard policy.

The Spitsbergen Treaty has been subject to differences in interpretation since its inception. For instance, Article 9's provisions on demilitarization have, in practice, been strongest in times of peace. In this, Svalbard may be compared with the Baltic archipelago of Åland, which was demilitarized by treaty in 1856 but was nevertheless subject to defensive military activity during both World War I and the 1939-1944 wars between Finland and the Soviet Union (Eriksson, 2006). Svalbard too was the scene of sporadic fighting during World War II. This followed the 1941 evacuation of Svalbard's residents (2,175 Russians and around 900 Norwegians) by Allied forces, which, in order to pre-empt German occupation, destroyed mines, buildings, oil and coal stocks, and machinery at all settlements (Dege, 2004/1954). In 1944, the Soviet Union sought unsuccessfully to place Svalbard under joint Norwegian-Soviet military control (Machowski, 1995). Norway's early entry into the North Atlantic Treaty Organization (NATO) and the 1950 creation of a NATO joint command covering Svalbard and Jan Mayen were reactions to concerns over Soviet expansionism (Lüdecke, 2011). As recently as 2010, debate flared up concerning the use for military purposes of photos of Iraq taken by the Norwegian-operated Svalbard Satellite station (Numminen, 2011).

Conflict has also arisen concerning Svalbard's territorial borders. The Spitsbergen Treaty predates legal concepts such as exclusive economic zones and maritime zones outside the territorial sea (Scotcher, 2011). Whereas Norway contends that the Spitsbergen Treaty covers only land and territorial sea to a distance of 12 nautical miles (around $22 \mathrm{~km}$ ), some other states regard the treaty as applying to the fisheries zone and the continental shelf (Anderson, 2007). When Norway set up a 200-nautical mile (around $370 \mathrm{~km}$ ) economic zone in 1977, the Soviet Union protested that this infringed on the rights of Spitsbergen Treaty signatories. In 2010, influenced by foreign policy considerations, Russia compromised on its claims and negotiated with Norway a maritime border in the Barents Sea (Arild et al., 2011). Disputes nevertheless continue regarding fisheries rights, with the Norwegian Coast Guard seizing the Russian trawler Sapphire II on 28 September 2011 (Nilsen, 2011).

Focus on such dramatic issues as demilitarization and fisheries zones risks, however, overlooking the day-to-day, mundane geopolitical positioning that Norway and other signatory states undertake in the archipelago. Whatever the interests of the community in Longyearbyen, the Norwegian government regards Longyearbyen primarily as an instrument of its 
sovereignty. Article 2 of the Spitsbergen Treaty sets forth the principle of non-discrimination, the equal treatment of nationals of all signatory states. The reason why the Longyearbyen Community Council does not fall afoul of the treaty - or has not been challenged as doing so is that Articles 2, 3, and 7 of the treaty concern only specified economic activities. The Government of Norway (1999: §4.1.2) argues that:

Where other kinds of activities are concerned, the Treaty does not afford any special rights to nationals of the other contracting parties. This means that measures in areas that are not specifically listed in the Treaty and that favour Norwegian nationals or otherwise discriminate between nationals of contracting parties may be carried out without hindrance of the Svalbard Treaty.

It is thus that Russia can operate Barentsburg as a mining town and also thus that all noneconomic activities may only take place at Norway's discretion (Government of Norway, 1999: §4.1.2).

Norway has been eager to openly assert sovereignty over Barentsburg (Government of Norway, 1999: §3.1). Umbreit (2009: 42-43) notes that, in the post-Soviet era:

Norway has made good use of the Russian weakness by gradually increasing its control over the Russians' activities, introducing more and more regulations and enforcing them, at least partly, within Russian settlements.

Regulations such as Norwegian-language road signs and Norwegian fire standards may appear innocuous, but such impositions of domestic law "could lead to conflicts with the nondiscrimination rule of the Spitsbergen Treaty as it is obviously more difficult for companies and employees from other countries to adapt to specific Norwegian standards" (ibid.). Indeed, as Russia has recovered its assertiveness in international relations, it has shown itself unwilling to simply submit to Norwegian control.

This is illustrated by Russia's successful struggle in the early 2000s to gain rights to open a new mine at Colesbukta, which could conceivably replace the nearly spent mines in Barentsburg proper. The Governor opposed this development on the basis of domestic Norwegian law, specifically the 2001 Svalbard Environmental Protection Act. Some Russian observers perceived the law as "a disguised political instrument aimed at forcing Russia off the archipelago" (Åtland \& Pedersen, 2009: 10-12). This conflict has also been interpreted as evidence of incompetence and lack of a cohesive Svalbard policy on the part of the Norwegian government (Jørgensen, 2004). However, as we have shown, Norway's Svalbard policy has in fact been quite focused and transparent since the start of the 1990s: while there is no evidence of a plot to destroy Barentsburg, the Norwegian government has undoubtedly sought to strengthen its sovereignty.

Russia's renewed commitment to Svalbard has been illustrated in smaller but no less telling ways, such as a recent dispute between the Governor and Trust Arktikugol over stewardship of $18^{\text {th }}$-Century Russian trapper artefacts (Aarskog, 2008a). These artefacts had been stored in allegedly poor conditions at Barentsburg's Pomor Museum. Because the Spitsbergen Treaty 
does not specify museum activities, the Governor again deployed the Svalbard Environmental Protection Act to demand that the artefacts be handed over for preservation in Longyearbyen. In other words, the operations of the Russian-run Pomor Museum were deemed to be at Norway's discretion. Yet the need for caution in exercising Norwegian sovereignty in Barentsburg is made clear by the Governor's subsequent climb-down following Russian protest (Aarskog, 2008b).

Another recent dispute involved Trust Arktikugol's operating of tourist helicopter flights from Longyearbyen to Barentsburg. Confronted with decreasing income from mining, Trust Arktikugol has sought to increase its income from tourists, who currently can only reach Barentsburg by snowmobile outside of the summer months. The Governor, however, contested that only flights directly related to Barentsburg's mining operations are protected by the Spitsbergen Treaty. Trust Arktikugol argued that tourism represents commercial activity covered by the Spitsbergen Treaty and that Norway's actions contravene the principle of nondiscrimination inasmuch as tourists have easy access to Longyearbyen, where Svalbard's only commercial airport is located, but not to Barentsburg. Following hearings in the Norwegian courts, Trust Arktikugol was fined for illegal flights and banned from operating them in the future (Amundsen, 2009).

This case had deep roots: already in the 1960s and 1970s, Russia complained that Norwegians received preferential treatment in terms of permission to operate helicopter flights. Historically speaking, Russia has consistently protested not only against being refused permission to undertake certain activities but also against being required to seek permission from the Governor prior to undertaking these activities (Arlov, 2011: 255-6). Norway's sovereignty over Svalbard is absolute only to the extent that it is not challenged and that Norway decides not to exert authority over controversial matters. One of the means by which the Norwegian government seeks to maintain the status quo is by quite concretely refusing to engage in international debate on revising the Spitsbergen Treaty (Østhagen, 2011).

Because the Spitsbergen Treaty is so open to interpretation, Svalbard's jurisdiction depends significantly on precedent and perception. It is usual to think of Russia as possessing special rights in Svalbard compared with other treaty signatories, yet this is the case only in practice, not in law. Russia's tenacious maintenance of a community at Barentsburg has ensured its continued influence in the territory, despite a world war, a cold war, the collapse of the Soviet Union, and periods of economic crisis. If, relative to the great tides of geopolitics, influence over museum displays, tourist flights, and an unprofitable mining operation appears petty, it is only because Russia's role in Svalbard has come to be taken for granted. This, it may be argued, is exactly what Russia wants. By any standards elsewhere in the world, the existence of a nearly untaxed state-run commercial outpost within another state's sovereign territory would be close to unthinkable. Barentsburg is vital to Russia in the same way as Longyearbyen is vital to Norway: they are important because they exist, rather than because important work is done there. 


\section{Scientific Research and Asia in the Arctic}

This is not deny that important work is done in Svalbard; it is only to explain why Svalbard in particular has been chosen as the site for such work, despite the many additional costs and difficulties that working in such a location entails.

Consider, for example, scientific research. In Svalbard, research cannot merely be taken at face value but must also be regarded as political activity engaged in by the national governments that fund the researchers. Even at the time of its establishment, the Norwegian Polar Institute was viewed as an instrument for achieving influence. Similarly, following the cessation of mining activities at Ny-Ålesund, Norway transformed the settlement into a research centre in part to prevent its being taken over by the Russians and in part to maintain Norway's status vis$\grave{a}$-vis other states that had begun oil exploration activities in Svalbard (Lüdecke, 2011: 256-259; Arlov, 2011: 247). When Norway decided in the 1980s to regard research and education as key economic activities for Svalbard's future (Arlov, 2011: 330), this was, as the Norwegian government itself states, aimed at "ensuring the continuation of Norwegian settlements" (Government of Norway, 1999: §3.3). Norway could, of course, have opened the UNIS university centre without recourse to redefining research and education as economic activity: the advantage to this redefinition lies in its ability to involve other Spitsbergen Treaty signatory states in the maintenance of Norwegian sovereignty.

This Norwegian strategy has been successful in the sense that research and education is now a major plank in Longyearbyen's economy (Government of Norway, 1999: §3.3). In addition, numerous countries now run research stations at Ny-Ålesund, thereby maintaining a second Norwegian settlement. The Svalbard Global Seed Vault, which opened in 2008, is similarly more than just a worthwhile endeavour to preserve genetic diversity of food crops; it is also an initiative that involves countless other countries (as seed contributors) assenting to Norway's sovereignty.

Nevertheless, Norway's research strategy has had a number of more ambiguous consequences. Besides encouraging the revitalization of Russian research in Barentsburg (Umbreit, 2009: 43) and the Polish Polar Station at Hornsundet, it has created a means for new actors to become involved in Svalbard; and thereby to exert influence over Arctic policy. For instance, Japan, South Korea, China, and India all operate research stations at Ny-Ålesund. Opened in 2004 as part of its wider Arctic strategy, China's Huanghe research station has been among the most active of such national stations, hosting a total of 36 project workers in 2010 (Numminen, 2011).

These Asian states wish to gain a place in the Arctic less for security concerns than for economic ones. Due to climate change, the Northern Sea Route and Northwest Passage are currently ice free in late summer and will likely be clear for longer and longer in the coming years. Use of these routes could massively reduce transport costs from Asia to Europe and the Eastern seaboard of the United States, cutting shipping distances by around 6,400 km and $7,000 \mathrm{~km}$ respectively. It has been estimated, for instance, that the Northern Sea Route could save China US\$60-\$120 billion annually (Bin Yang, cited in Byers, 2011a). South Korea, meanwhile, wishes to boost its powerful shipbuilding industry by expanding into Arctic vessels 
(Exner-Pirot, 2011). Chinese researchers have stressed both the economic importance of dominating the emergent Arctic trade routes and the ways in which use of these routes could encourage Asian regional cooperation (Jakobsen, 2010: 6-7). So far, China's Arctic policy has focused on research in the natural sciences; yet some Chinese researchers are calling for China to take a more politically informed approach and directly engage with other states on political questions regarding the Arctic (Guo Peiqing, cited in Jakobsen, 2010: 7).

The question for the Asian states is how such political engagement might be structured. The closest thing to a regional policymaking body is the Arctic Council. Japan, South Korea, and China have all unsuccessfully applied on one or more occasions for permanent observer status on the Arctic Council. Their exclusion from this body (except as ad hoc observers) leaves them without a voice in policy development. The states currently holding permanent observer status on the Arctic Council are France, Germany, the Netherlands, Poland, Spain, and UK, none of which, arguably, hold as significant economic stakes in the region as do the Asian states in question. Asia's fear is that Arctic policy cannot be left solely in the hands of the Arctic littoral states, all of which advance expansive continental shelf claims and may have difficulty acting in the global - rather than solely national - interest (Jakobsen, 2010: 9-10). The Norwegian government is adapting to developments as they occur and has supported China's request for permanent observer status on the Arctic Council, expressing an interest in bilateral economic and scientific ties (Støre, 2010). This can also be read as an attempt to prevent Russia from becoming China's key regional partner.

It is in this international context that Bailes (2011: 36) muses whether the Spitsbergen Treaty has continued to accrue signatories precisely "because there is no other easy point of entry, as yet, for states who seek footholds - including a base for direct participation in research within the High North region". Being a Spitsbergen Treaty signatory provides only an indirect influence on Arctic policymaking; but in the absence of other options, Norway's efforts to make Svalbard central to regional policy offers signatory states the opportunity to have some influence on the future of the Arctic.

\section{Conclusion}

Although the Spitsbergen Treaty created a legislative framework for discussing the 'Svalbard question', the question itself remains unresolved. Since the end of the Cold War, focus has declined on the possibility of outright military conflict between the East and the West. Instead, Svalbard has increasingly become subject to strategic concerns related to the world economy. Norway and Russia may be fighting the same old battles in Svalbard, but they are doing so in new ways: the Norwegian government makes no effort to hide that its maintenance of sovereignty over Svalbard is an end in itself, and Russia has shown a willingness to spend money and engage the Norwegian courts for the sake of its presence in the territory. As far as these two countries are concerned, the nurturing of national rights in Svalbard is necessary not so much for the benefits these rights convey as for the way in which they deny other states the strategic benefits that hegemony over Svalbard could potentially bestow. This point was corroborated by Robert Hermansen (quoted in Brown, 2000), former CEO of Store Norske, who said in 2000: 
To keep control of Svalbard we have to have a community here. If we left, the Russians would immediately claim it. I am under no illusions (Brown, 2000, n.p.).

Barentsburg and Longyearbyen are thus likely to exist long into the future, regardless of whether any coal remains for these mining communities to mine.

In practice, among the Spitsbergen Treaty signatories, Russia is uniquely capable of constraining Norway's efforts at exercising absolute sovereignty. Echoes of the Cold War era's securitization rhetoric notwithstanding (Åtland \& Pedersen, 2009), Russia's role in the archipelago is one that suits the interests of many other signatory states, which in a sense depend on Russia's resistance to Norwegian sovereignty in order to retain their own rights. Russia may be the most vocal opponent of Norway's continental shelf claims concerning Svalbard, but many other signatories disagree with these claims as well (Numminen, 2011). These signatories are willing to leave the fighting of such battles to Russia so they need not get their own diplomatic hands dirty.

Norway's attempts to assert its sovereignty vis-à-vis Russia by creating a genuine community in Longyearbyen and by encouraging scientific research may have relatively weakened Russia's hand. They have, however, done so at the cost of strengthening the hands of all other signatory states. Today, Norway is no longer in direct control of who lives in Longyearbyen and what work the town's residents carry out. As local decision making becomes further entrenched in the community, there is every possibility that demands will arise for this decision making to take place in a more democratic framework, one that is freer from the Governor and that reflects the views of the community's residents as a whole, not just its Scandinavian residents. Now that the Longyearbyen liberalization genie is out of the bottle, there is no way of stuffing it back in, at least not without cutting off Longyearbyen's external funding and thereby sacrificing the strongest instrument of Norwegian sovereignty.

Returning to the international relations plane, it is still too early to assess the consequences of Norway's promotion of scientific research and multinational development in Svalbard. The Norwegian government's consistent privileging of the Spitsbergen Treaty to support its continental shelf claims and position itself at the centre of Arctic policy has turned Norway into a pivotal player in Asia's Arctic expansion. By facilitating the introduction of new actors into the region, however, Norway risks diluting the influence of the Arctic littoral states as a group. On the other hand, Norway's shipping, shipbuilding, and engineering industries may benefit from the country being a strategic partner of the Asian economic powerhouses, which are being pushed to use Svalbard as a staging ground for wider involvement in the region. In any case, as long as Norway proclaims itself the sole arbiter of the terms of the Spitsbergen Treaty, it cannot very well complain when other states exploit Norway's interpretations for their own strategic ends.

Norway is thus in a difficult situation, partly of its own making; a situation that presents the country with both great opportunities and significant risks. Over the past two decades, Svalbard has become home to a truly global local community as well as a cornerstone of various states' international relations and trade ambitions. The Spitsbergen Treaty, crafted over 90 years ago, has thus had an unusual (and in many ways unintended) legacy. 
Svalbard has long been a focus of interest from the perspectives of international law and security studies. In the future, the island territory also deserves greater attention for the way in which its residents and the states that support them reflect developments in globalization.

\section{References}

Aarskog, K.N. (2008a) 'Vil overta museumsgjenstander', Svalbardposten, 30 October, http://svalbardposten.no/node/1534

Aarskog, K.N. (2008b) 'Avverget politisk konflikt', Svalbardposten, 7 November, http://svalbardposten.no/node/1522

Amundsen, B. (2009) 'Dom stanser turist planer i Barentsburg', Svalbardposten, 20 November, www.svalbardposten.no/nyheter/dom-stanser-turistplaner-i-barentsburg

Anderson, D.H. (2007) 'The Status under International Law of the Maritime Areas around Svalbard", Paper presented at the Symposium on "Politics and Law - Energy and Environment in the Far North", held at the Norwegian Academy of Science and Letters, 24 January.

Arild, M., D. Fjærtoft \& I. Øverland (2011) 'Space and Timing: Why was the Barents Sea Delimitation Dispute Resolved in 2010?’, Polar Geography, Vol. 34, No. 3, pp. 145-162.

Arlov, T.B. (2011) Den rette mann: Historien om Sysselmannen på Svalbard, Trondheim, Tapir Akademisk Forlag.

Åtland, K. \& T. Pedersen (2009) 'Russia's Svalbard Policies: Securitization Still in Fashion?', Paper presented at $50^{\text {th }}$ Annual Convention, International Studies Association, New York, 15 February, http://citation.allacademic.com//meta/p_mla_apa_research_citation/3/1/3/2/0/pages313206/p313 206-1.php

Bailes, A. (2011) 'Spitsbergen in a Sea of Change', in D. Wallis and S. Arnold (eds.) The Spitsbergen Treaty: Multilateral Governance in the Arctic, Helsinki, Arctic Papers, Vol. 1, pp. $34-37$.

Brown, P. (2000) 'Coal makes Oslo king of the isles', The Guardian, 30 December, www.guardian.co.uk/environment/2000/dec/30/internationalnews

Byers, M. (2011a) 'The dragon looks north', Al Jazeera, 28 December, www.aljazeera.com/indepth/opinion/2011/12/20111226145144638282.html

Byers, M. (2011b) 'Russia pulling ahead in the Arctic', The Star, 29 December, www.thestar.com/opinion/editorialopinion/article/1108138--russia-pulling-ahead-in-the-arctic 
Dege, W. (2004/1954) War North of 80: The Last German Arctic Weather Station of World War II, W. Barr (trans. and ed.), Calgary $\mathrm{AB}$ and Boulder CO, University of Calgary Press, University of Colorado Press, with the Arctic Institute of North America.

Emmerson, C. (2010) The Future History of the Arctic, New York, Public Affairs.

Eriksson, S. (2006) 'Åland - A demilitarised and neutralised territory', in S. Eriksson, L.I. Johansson, \& B. Sundback (eds.) Islands of Peace: Aland's Autonomy, Demilitarization, and Neutralization, Mariehamn, Åland Islands Peace Institute, pp. 9-35.

Exner-Pirot, H. (2011) 'What route for Arctic shipping?', Arctic: Views from Up North, 25 March, http://eyeonthearctic.rcinet.ca/en/blog/136-heather-exner-pirot/793-what-route-for-arcticshipping

Fife, R.E. (2008) 'Svalbard and the surrounding maritime areas: Background and legal issues', Norwegian Ministry of Foreign Affairs, 26 November, www.regjeringen.no/en/dep/ud/selectedtopics/civil--rights/spesiell-folkerett/folkerettslige-sporsmal-i-tilknytning-ti.html?id=537481

Government of Norway (1999) Report No. 9 to the Storting (1999-2000): Svalbard, www.regjeringen.no/en/dep/jd/Documents-and-publications/Reports-to-the-Storting-White-

Papers/Reports-to-the-Storting/19992000/report-no-9-to-the-storting-.html?id=456868

Government of Norway (2001) Ot.prp. Nr. 58 (2000-2001): Lov om endringer til svalbardloven mm. (innføring av lokaldemokrati $i$ Longyearbyen), www.regjeringen.no/nb/dep/jd/dok/regpubl/otprp/20002001/otprp-nr-58-2000-2001$\underline{\text { /2.html? id }=164762}$

Governor of Svalbard (2008) 'Settlements', www.sysselmannen.no/hovedEnkel.aspx?m=45299

Grydehøj, A. (2010) 'Uninherited Heritage: Community Reaction to Heritage without Inheritors in Shetland, Åland, and Svalbard', International Journal of Heritage Studies, Vol. 16, Nos. 1-2, pp. 77-89.

Grydehøj, A. \& P. Hayward (2011) 'Autonomy Initiatives and Quintessential Englishness on the Isle of Wight', Island Studies Journal, Vol. 6, No. 2, pp. 179-202.

Jakobsen, L. (2010) 'China prepares for an ice-free Arctic', SIPRI Insights on Peace and Security, Stockholm, Stockholm International Peace Research Institute.

Jensen, A.M. (2009) 'From Thailand to Svalbard: Migration on the margins', Asia Portal - In Focus, http://infocus.asiaportal.info/2009/05/25/mayfrom-thailand-svalbard-migration-marginsan-magritt-jensen

Jørgensen, J.H. (2004) 'Ønsker Norge å presse Russland bort fra Svalbard?', Aftenposten, 04 January, www.aftenposten.no/meninger/kronikker/article701483.ece 
Lüdecke, C. (2011) 'Parallel Precedents for the Antarctic Treaty', in P.A. Berkman, M.A. Lang, D.W.H. Walton, \& O.R. Young (eds.) Science Diplomacy: Antarctica, Science, and the Governance of International Spaces, Washington DC, Smithsonian Institution, Scholarly Press, pp. 253-263.

Machowski, J. (1995). 'Scientific Activities on Spitsbergen in the Light of the International Legal Status of the Archipelago', Polish Polar Research, Vol. 16, Nos. 1-2, pp. 13-35.

Moczadlowski, T. (2001) Polska Stacja Polarna: Hornsund, http://hornsund.igf.edu.pl

Nilsen, T. (2011) 'Russians must follow Norwegian law', BarentsObserver.com, 14 October, www.barentsobserver.com/-russians-must-follow-norwegian-law.4972044.html

Norwegian Ministry of Foreign Affairs (2006) The Norwegian Government's High North Strategy, www.regjeringen.no/upload/UD/Vedlegg/strategien.pdf

Norwegian Polar Institute (2011) 'Svalbard', www.npolar.no/en/the-arctic/svalbard

Numminen, L. (2011) 'A History and Functioning of the Spitsbergen Treaty' In D. Wallis and S. Arnold (eds.) The Spitsbergen Treaty: Multilateral Governance in the Arctic, Helsinki, Arctic Papers, Vol. 1, pp. 7-20.

Permanent Court of International Justice (1933) Fascicule No. 53: Legal Status of Eastern Greenland, Leiden, The Netherlands, A.J. Sijthoff.

Scotcher, N. (2011) 'The Sovereignty Dilemma', D. Wallis and S. Arnold (eds.) The Spitsbergen Treaty: Multilateral Governance in the Arctic, Helsinki, Arctic Papers, Vol. 1, pp. 21-33.

Statistics Norway (2011a) 'Accommodation on Svalbard, July 2011', www.ssb.no/english/subjects/10/11/overnattingsv en

Statistics Norway (2011b) 'Population Statistics. Svalbard’, www.ssb.no/befsvalbard en

Statistics Norway (2011c) 'Svalbard's History', www.ssb.no/this is_Svalbard

Statistics Norway (2011d) 'Industrial Statistics for Svalbard 2010', www.ssb.no/english/subjects/10/sts_en

Store Norske (2011) 'Annual Report and Accounts: 2010', www.snsk.no/annual-report-andaccounts.148181.en.html

Store Norske (2010) 'Important Dates in Store Norske’s History', www.snsk.no/important-datesin-store-norskes-history.145749.en.html 
Støre, J.G. (2010) 'Arktis - norsk politikk og internasjonalt samarbeid', Speech given at China Institute of International Studies, Beijing, 30 August, Norwegian Ministry of Foreign Affairs, www.regjeringen.no/nb/dep/ud/aktuelt/taler_artikler/utenriksministeren/2010/ciis beijing.html?i $\underline{\mathrm{d}=613162}$

The Svalbard Treaty 9 February 1920, Available at University of Oslo, Faculty of Law, www.jus.uio.no/english/services/library/treaties/01/1-11/svalbard

Terrapolaris (2010) 'Pyramiden - Settlement, Accommodation, Travel', www.terrapolaris.com/index.php?id $=338 \& \mathrm{~L}=5$

Tobias, B. (2006) 'Cold War Haunts Arctic Outpost', BBCRussian.com, http://news.bbc.co.uk/1/hi/world/europe/6204427.stm

Umbreit, A. (2009) Spitsbergen, Bucks UK, Bradt Travel Guides.

Webb, M. (1992) 'Arctic Saga: Vilhjalmur Stefansson's Attempt to Colonize Wrangel Island', Pacific Historical Review, Vol. 61, No. 2, pp. 215-239.

Ween, S.O. (2011) 'Longyearbyen lokalstyre', www.lokalstyre.no/Modules/theme.aspx?ObjectType $=$ Article\&ElementID $=630 \&$ Category. $. \mathrm{ID}=7$ $\underline{07}$

Wråkberg, U. (2002) 'The Politics of Naming: Contested Observations and the Shaping of Geographical Knowledge', in M. Bravo and S. Sèorlin (eds.), Narrating the Arctic: A Cultural History of Nordic Scientific Practices, Canton MA, Watson, pp. 155-198.

Østhagen, A. (2011) 'Debating the EU's Role in the Arctic: A Report from Brussels', The Arctic Institute, Centre for Circumpolar Security Studies, www.thearcticinstitute.org/2011/10/2472european-arctic-ambiguity.html 